\title{
Обґрунтування застосування антиоксидантної терапії в комплексному консервативному лікуванні синдрому діабетичної стопи
}

\author{
О.О. Біляєва' ${ }^{1}$ O.І. Осадча", Є.Є. Крижевський ${ }^{1}$, А.Р. Бітіньш' \\ 'Національний університет охорони здоров'я України імені П.Л. Шупика, Київ, Україна \\ ${ }^{2}$ Національний університет фізичного виховання і спорту України, Київ, Україна
}

\begin{abstract}
Анотація. Мета: вивчити стан антиоксидантної системи пацієнтів із синдромом діабетичної стопи та покращити результати їх комплексного лікування. Об'єкт і методи дослідження. У дослідження увійшло 134 хворих із синдромом діабетичної стопи. Їх розподілено за статтю та віком: чоловіків - 85 (63,4\%), жінок - 49 (36,6\%), середній вік 64,3 7,3 року. Для вивчення антиоксидантної системи у хворих на 1-шу, 7-му та 14-ту добу визначали в рані та сироватці крові вміст метаболітів активних форм кисню - ТБК-активних продуктів в плазмі крові, активність антиоксидантної системи - супероксиддисмутази. Показники функціональної активності моноцитів периферичної крові оцінювали в тесті відновлення нітросинього тетразолію в двох модифікаціях: спонтанному та індукованому ліпополісахаридом. Результати. При визначенні активності супероксиддисмутази у периферичній крові у хворих, які в комплексному лікуванні отримували глутатіон, встановлено зниження їі активності відносно референтних значень у 1,56 раза ( $<<0,001)$. Висновок. Оксидативний стрес призводить до каскаду патоморфологічних змін в організмі, що диктує необхідність застосування антиоксидантної терапії в комплексному лікуванні при синдромі діабетичної стопи.
\end{abstract}

Ключові слова: синдром діабетичної стопи, цукровий діабет, антиоксидантна система.

\section{Вступ}

Цукровий діабет (ЦД) - одна з патологій, яка швидко розповсюджується у XXI ст. Багато авторів відмічають, що кількість дорослих, які живуть з ЦД, за останні 20 років збільшилася В >3 рази [1-3]. Як прогнозували багато експертів, поширеність ЦД продовжує збільшуватися. У близько 425 млн осіб в усьому світі відмічають ЦД [4].

При ЦД, як правило, прискорюються процеси вільнорадикального окиснення ліпідів, що призводить до оксидативного стресу, який чинить ушкоджувальну дію на судини та гемореологічний стан організму. Причиною оксидативного стресу при ЦД $\epsilon$ стан хронічної гіперглікемії [5].

Однією з причин порушень в організмі при ЦД $є$ оксидативний стрес. Цей патологічний процес виникає при багатьох захворюваннях. Посилення окисних процесів при недостатності системи антиоксидантного захисту підтримує розвиток оксидативного стресу, що $є$ одним з універсальних механізмів пошкодження тканин організму [6].

Ішемія, гіпоксія тканин, що відмічаються при ЦД, є додатковими факторами, що зумовлюють підвищене утворення реактивних оксидантів в різних органах і тканинах.

Вільнорадикальні процеси вважаються необхідною ланкою таких життєво важливих функцій: транспорт електронів ланцюга дихальних ферментів, синтез простагландинів і лейкотрі$\epsilon$ нів, проліферація і диференціювання клітин тощо. Ці процеси $\epsilon$ універсальними патофізіологічними феноменами, роль яких доведена при >100 різних захворюваннях. В організмі людини виявлено складний ланцюг взаємопов'язаних вільнорадикальних процесів, в які втягуються білки, нуклеїнові кислоти, ліпіди та фосфоліпіди $[7,8]$.

Оксидативний стрес $€$ невід'ємним при метаболічних порушеннях при ЦД, оскільки являє собою порушення балансу між прооксидантами і системою антиоксидантного захисту, який супроводжує дефіцит інсуліну або інсулінорезистентність, що $\epsilon$ одним із обов'язкових компонентів патогенезу судинних ускладнень при ЦД. При цьому відмічається надмірне утворення вільних радикалів, що призводить до пошкодження клітин, тканин і органів $[9,10]$.

В умовах гіперглікемії атеросклероз прогресує в результаті окисної модифікації ліпопротеїдів низької щільності 3 подаль- шим посиленням поглинання моноцитами, які перетворюються в пінисті клітини, що беруть участь у доатерогенній ліпідній інфільтрації судинної стінки [11, 12].

В організмі існує антиоксидантна система і основним антиоксидантом $\epsilon$ глутатіон.

Основною функцією системи глутатіону (GSH) є захист клітин від активних форм кисню, вироблення яких значно підвищується при ЦД. Антиоксидантний захист організму від впливу перекису водню здійснюється GSH і каталазою, але в мітохондріях, де каталаза відсутня, антиоксидантний захист здійснюється GSH [13-15].

Відновлений глутатіон (GSH) - низькомолекулярний тіол, що переважає (90-95\%) у багатьох рослинних, мікробних і у тваринних клітинах, в яких його молярна концентрація (1-10 мМ) вища, ніж концентрація більшості органічних речовин. Його пряма функція - руйнування вільних радикалів. Він $\epsilon$ трипептидом (L-гамма-глутаміл-L-цістеїнілгліцин), біосинтез і катаболізм якого описуються так званим глутамільним циклом [16].

Глутатіон у відновленій формі може функціонувати як антиоксидант багатьма способами: хімічно взаємодіяти з синглетним киснем, супероксидом і радикалами гідроксилу або напряму руйнувати вільні радикали; стабілізувати мембранну структуру переміщенням ацетилпероксидів, що утворюються шляхом перекисного окиснення ліпідів (ПОЛ). GSH $\epsilon$ коферментом ряду ферментів, активність яких базується на зміні редокс-потенціалу глутатіону. Активність глутатіонпероксидази (GPO) і швидкість утилізації перекису водню безпосередньо залежать від концентрації відновленого глутатіону в клітині [17].

Кон'югування ксенобіотиків і виведення пероксидів ліпідів клітинних мембран, яке здійснюється глутатіон-S-трансферазою (GST), не відбувається без GSH. Відновлений глутатіон необхідний для підтримки реакцій аскорбат-глутатіонового циклу, пов'язаного з нейтралізацією перекису водню. Основний же пул відновленого глутатіону підтримує глутатіонредуктаза, яка $\epsilon$ невід'ємним елементом цього циклу. Головний орган синтезу глутатіону — печінка, яка забезпечує близько 90\% всього циркулюючого глутатіону при фізіологічних умовах [18].

Для вибору стратегії лікування при синдромі діабетичної стопи (СДС) потрібно визначати його стадію та форму. В нашій 
роботі ми використовуємо класифікацію Wagner - Meggitt, яку описав B. Meggitt у 1976 р. [20] і поширив F. Wagner у 1979 р. [21]. Вона включає 6 стадій: 0 - передвиразкова або післявиразкова ділянка, 1 - поверхнева виразка, 2 - виразка, що проникає у сухожилля або суглобову капсулу, 3 - абсцеси глибоких тканин, остеомієліт, 4 - гангрена дистальної частини стопи, 5 - гангрена цілої стопи, яка охоплює $>2 / 3$ стопи [22]. Також використовується класифікація СДС, запропонована на 1-му Міжнародному симпозіумі з діабетичної стопи у 1991 р. (Нідерланди), яка ґрунтується на патогенезі розвитку цього ускладнення ЦД і включає нейропатичну, ішемічну та нейроішемічну форми.

Лікування хворих із СДС залежить від переважання нейропатичного чи ішемічного компоненту захворювання, а також стадії СДС за класифікацією Wagner. Хворих з I та II стадіями за класифікацією Wagner спостерігають та лікують у кабінетах діабетичної стопи спільно з ендокринологом, невропатологом, подологом. Основним методом лікування хворих з СДС III-V стадії за класифікацією Wagner $\epsilon$ xірургічне, що потребує лікування в стаціонарі.

Таким чином, оксидативний стрес $\epsilon$ складовою патофізіологічних змін в організмі хворого на ЦД, що потребує його вивчення та визначення тактики лікування.

Мета: вивчити стан антиоксидантної системи хворих із СДС та покращити результати їх комплексного лікування.

\section{Об'єкт і методи дослідження}

У відділенні гнійної хірургії КНП «Київська міська клінічна лікарня № 6» протягом 2019 р. перебували на лікуванні 2114 хворих з різними хірургічними захворюваннями, 3 них 1073 (50,7\%) 3 гнійно-запальними захворюваннями та ускладненнями, серед них з ЦД 2-го типу - 193 (17,9\%) хворих, з СДС - 151 (14,1\%), в II-V стадії за класифікацією Wagner - 134 (12,5\%), які госпіталізовані за екстреними показаннями, їм виконано хірургічне втручання. У 17 хворих виявлено I стадію за класифікацією Wagner, хірургічне втручання цим хворим не проводили.

У дослідження включили 134 хворих із СДС. Їх розподілено за статтю та віком: чоловіків - 85 (63,4\%), жінок - 49 (36,6\%),

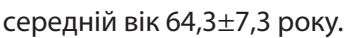

В усіх хворих відмічали супутні захворювання, які впливають прямо або опосередковано на результати лікування: ішемічну хворобу серця - у $108(80,6 \%)$, гіпертонічну хворобу - у 97 (72,4\%), гостре порушення мозкового кровообігу в анамнезі - у 17 (12,7\%), інфаркт міокарда в анамнезі у $23(17,2 \%)$, енцефалопатію - у 29 (21,6\%), хронічну ниркову недостатність - у $16(11,9 \%)$, варикозну хворобу нижніх кінцівок - у 14 (10,5\%), діабетичну ретинопатію - у 53 (39,6\%) хворих.

Для класифікації тяжкості і глибини гнійно-некротичного ураження тканин хворі розподілені за класифікацією Wagner наступним чином: II стадія - у 9 (6,7\%), III - у 49 (36,6\%), IV у 55 (41\%), V - у 21 (15,7\%) пацієнтів.

Хворим з СДС проводили комплексне дослідження, яке включає визначення суб'єктивних симптомів нейропатії, клінічних проявів СДС, неврологічної симптоматики, а також лабораторні та інструментальні дослідження.

Для вибору тактики лікування СДС необхідно досліджувати кісточково-плечовий індекс, який $є$ об'єктивним методом визначення ступеня артеріальної оклюзії у хворих із СДС [23].

Для вивчення антиоксидантної системи у пацієнтів із СДС на 1-шу, 7-му та 14-ту добу визначали в рані та сироватці крові вміст метаболітів активних форм кисню - ТБК-активних продуктів в плазмі крові [24], активність антиоксидантної системи супероксиддисмутази (СОД) [25], вміст метаболітів оксиду азоту, S-нітрозотіолів [26, 27].

Показники функціональної активності моноцитів периферичної крові оцінювали в тесті відновлення нітросинього тетразолію в двох модифікаціях: спонтанному та індукованому ліпополісахаридом [28].

Для отримання хороших результатів лікування такого складного захворювання, як СДС, потрібен комплексний підхід.
Лікування хворих на СДС здійснюється у двох напрямках: консервативному та хірургічному з урахуванням патогенезу та клінічної форми СДС і включає:

- хірургічне лікування гнійно-некротичного вогнища з імобілізацією стопи;

- корекцію вуглеводного обміну (перехід на інсулінотерапію);

- антибактеріальну терапію;

- метаболічну терапію (препарати а-ліпоєвої кислоти, вітаміни групи В);

- антикоагулянтну терапію;

- антиагрегантну терапію;

- ангіотропну терапію;

- знеболювальну та протизапальну терапію;

- місцеве лікування ран різними препаратами залежно від фази перебігу ранового процесу;

У зв'язку з тим, що наше дослідження присвячене консервативному лікуванню СДС, дані хірургічного лікування, яке $\epsilon$ основоположним у комплексному лікуванні СДС, у цій статті не представлені.

При терапії пацієнтів із СДС найважливішим завданням $\epsilon$ нормалізація показників вуглеводного обміну. Постає запитання - чи переводити хворого на інсулінотерапію? Особливо це важливо при підготовці до хірургічного втручання. Більшість авторів дотримуються наступної тактики: переведення хворих на простий інсулін протягом 2-3 днів до та через 7-8 днів після хірургічного втручання.

При лікуванні хворих із СДС ми дотримуємося індивідуального підходу, орієнтуємося на терапію ЦД, яку хворий отримував до госпіталізації, глікемічний профіль та рівень глікозильованого гемоглобіну.

Для корекції вуглеводного обміну перед хірургічним втручанням хворого обов'язково переводимо на простий інсулін, тому що не тільки вміст глюкози в крові, але й концентрація інсуліну мають значення для нормального загоєння ран та профілактики гнійно-запальних ускладнень. Оцінка стану вуглеводного та ліпідного обміну $\epsilon$ абсолютно необхідним компонентом обстеження.

Антибіотикотерапія за значущістю займає 2-ге місце в комплексному лікуванні СДС після хірургічного лікування.

Важливу роль у досягненні результатів лікування відіграє стартова адекватна антимікробна терапія з дотриманням деескалаційного принципу антибіотикотерапії. Застосовувані антибіотики повинні мати здатність проникати в зони інфекції, особливо в кісткову тканину, створюючи там бактерицидну концентрацію, мати широкий спектр дії, охоплювати аеробні й анаеробні збудники. При лікуванні тяжких форм гнійно-некротичних ускладнень необхідно застосовувати комбіновану антибактеріальну терапію. Таку дію чинять препарати групи фторхінолонів (ципрофлоксацин, левофлоксацин та ін.) у поєднанні з препаратами групи нітроімідазолів (метронідазол, орнідазол, тинідазол та ін.).

У разі наявності у хворого із СДС остеомієліту необхідно призначати комбінацію антибіотиків, що накопичуються в кістковій тканині, - лінкоміцин, кліндаміцин, фторхінолони [29].

3 метою дотримання принципу деескалаційної антибіотикотерапії всім хворим проводимо бактеріологічне дослідження ранового вмісту з визначенням чутливості до антибіотиків.

Проаналізовані результати мікробіологічних досліджень з ран у хворих на СДС та виявлені основні збудники хірургічної інфекції такі: Staphylococcus aureus - 41,9\%, Proteus mirabilis $22,3 \%$, Escherichia coli - 13,7\%, Pseudomonas aeruginosa - 8,2\%, Staphylococcus epidermidis - 4,5\%, Enterobacter species - 4,1\%, Streptococcus pyogenes - 2,9\%, Acinetobacter baumannii - 2,4\%.

За даними антибіотикограми, чутливість до ципрофлоксацину становила 90,3\%, до левофлоксацину - 91,7\%, до гентаміцину $-73,6 \%$, до цефтріаксону - 68,7\%, до іміпенему - 93,9\%, до фосфоміцину - 48,2\%, до ванкоміцину - 88,3\%, лінезоліду $-78 \%$, тайгецикліну $-88,3 \%$. 
Таким чином, дані нашого дослідження підтверджують, що при СДС слід призначати фторхінолони, які накопичуються і в кістковій тканині.

Велике значення для отримання позитивних результатів лікування СДС має адекватна знеболювальна терапія у поєднанні з нестероїдними протизапальними препаратами.

У комплексному лікуванні СДС ми призначаємо метаболічні препарати і вітамінотерапію. Одним із еффективних метаболічних препаратів $\epsilon$ a-ліпоєва кислота, яка виконує такі важливі функції, як активізація ферментів мітохондрій, пригнічення процесів глюконеогенезу, кетогенезу, підвищення чутливості до інсуліну, збільшення транспорту глюкози, посилення окиснення глюкози, пригнічення ліполізу, відновлення рівня GSH, зниження рівня продуктів ПОЛ, запобігання глікозилюванню білків.

Згортальна система крові визначається станом гемостазу, в який входить наступне: стан тромбоцитів, фактори коагуляції та порушення цілісності судинної стінки. При порушенні одного із зазначених компонентів виникає тромбоутворення. Багатьма дослідниками доведено, що при ЦД відмічається порушення всіх трьох компонентів, особливо висока адгезивність тромбоцитів та їх агрегація. Процес порушення згортальної системи крові при ЦД складний, і його вивченню присвячено багато досліджень.

Таким чином, при СДС відмічається гіперкоагуляція, що потребує призначення в складі комплексного лікування антикоагулянтної терапії (низькомолекулярні гепарини, антиагреганти та ангіотропні препарати).

Дослідженнями доведено, що під впливом цилостазолу знижується агрегація тромбоцитів у пацієнтів із хронічною венозною недостатністю в поєднанні з СДС, агрегація тромбоцитів на 10-ту добу знижується у 1,8 раза. Отримані дані обґрунтовують необхідність призначення цилостазолу в комплексній терапії СДС.

Основним показанням до застосування антиоксидантів $\epsilon$ недостатність власної антиоксидантної системи при ЦД, надмірне утворення вільних радикалів та розвиток оксидативного стресу. Ми призначаємо хворим глутатіон, який $\epsilon$ трипептидною біологічно активною сполукою, що складається 3 трьох амінокислот: L-глутамінової кислоти, гліцину і L-цистеїну. Відновлена форма глутатіону (GSH) захищає SH-групи білків від окиснення різними окиснювальними чинниками. Механізм захисту клітин полягає в окисненні SH-групи самого глутатіону з утворенням окисненої форми і збереженням SH-груп білків в активній відновленій формі. Це сильний антиоксидант, що захищає клітини від пошкодження вільними радикалами. У проведених дослідженнях глутатіон довів здатність стимулювати проліферацію Т-лімфоцитів.

Глутатіон ми призначаєм per os по 500 мг 1 раз на добу під час лікування в стаціонарі з наступним застосуванням протягом 1-3 міс. Глутатіон сприяє корекції порушень вуглеводного і ліпідного обмінів та нормалізації рівня глюкози в крові.

\section{Результати та їх обговорення}

При визначенні активності СОД периферичної крові у хворих, які в комплексному лікуванні отримували глутатіон, встановлено зниження ії активності відносно референтних значень у 1,56 раза $(\mathrm{p}<0,001)$. При цьому в 2 -му періоді досліджень визначена тенденція до підвищення активності СОД відносно вихідних значень в 1,06 раза при значному зниженні відносно референтних - в 1,17 раза $(p<0,001)$. В подальшому, в 3-му періоді дослідження, встановлено підвищення активності СОД відносно вихідних показників у 1,25 раза $(p<0,001)$, однак зниження - відносно референтних.

Встановлено підвищення вмісту ТБК-активних продуктів в периферичній крові в 1-му періоді дослідження відносно референтних значень у 1,60 раза $(p<0,001)$. В 2-му періоді дослідження встановлена тенденція до зниження показників вмісту ТБК-активних продуктів в периферичній крові відносно вихідних значень у 1,19 раза $(p<0,001)$, при цьому вони перевищували референтні. В 3-му періоді дослідження встановлено зниження вмісту ТБК-активних продуктів в периферичній крові відносно вихідних значень у 1,57 раза $(p<0,001)$.

Виявлено підвищення вмісту ПОЛ в периферичній крові відносно референтних значень у 5,89 раза ( $<<0,001)$. В 2-му та 3-му періоді досліджень встановлено зниження вмісту ПОЛ відносно вихідних значень у $1,19(p<0,001)$ та $1,60(p<0,001)$ раза відповідно, при цьому ці значення перевищували референтні.

При визначені вмісту S-нітрозотіолів в периферичній крові зафіксовано підвищення показників відносно референтних у 2,27 раза $(p<0,001)$, в 2-му періоді досліджень по відношенню до вихідних - у 1,11 раза $(p<0,05)$, в 3-му періоді досліджень показники були знижені відносно вихідних у 1,13 раза $(\mathrm{p}<0,05)$ (табл. 1).

S-нітрозотіоли беруть участь в регуляції клітинного циклу, апоптозу, а також функціонального стану мітохондрій. Надмірне утворення S-нітрозотіолів може викликати незворотну блокаду внутрішньоклітинного дихання і токсичне ушкодження клітин. В умовах вільнорадикального пошкодження і порушення синтезу СОД надмірне утворення S-нітрозотіолів і асоційованого $з$ ними пероксинітриту, ймовірно, пов'язано з активацією NOсинтази в лейкоцитах периферичної крові, що посилює вазоконстрикторні реакції.

Дефіцит антиоксидантної системи (СОД), розвиток оксидативного стресу зумовлюють значне підвищення концентрації ТБК-активних форм кисню, при цьому ТБК-активні форми кисню агресивно взаємодіють з оксидом азоту, знижають його біодоступність, що відіграє значну роль в розвитку ендотеліальної дисфункції в зоні некротичного ушкодження та активує вазоконстрикторні цитокіни, а саме гомоцистеїн та ендотелін-1, що призводить до подальшого збільшення активних форм кисню та розвитку пошкодження клітин. Порушення кровопостачання в тканинах зумовлює гіпоксію і ще більшу генерацію вільних радикалів.

Надмірне утворення продуктів ПОЛ викликає пошкодження макрофагів/моноцитів, що зумовлює зниження їх функціональної активності як основних ефекторних клітин неспецифічної резистентності та антимікробного захисту організму хворого на ЦД.

При вивченні функціональної активності моноцитів в 1-му періоді дослідження встановлено зниження показників відносно референтних значень у 1,5 раза $(p<0,05)$ в спонтанному тесті і у 2,11 раза $(p<0,05)-$ в індукованому. В 2-му періоді дослідження виявлено, що показники функціональної активності моноцитів в індукованному тесті були вище вихідних значень в 1,79 раза. В 3-му періоді дослідження встановлено підвищення функціональної активності моноцитів в індукованному тесті відносно вихідних значень в 2,56 раза $(\mathrm{p}<0,05)$ (табл. 2).

Таблиця 1 Показники активності метаболічних процесів в периферичній крові у хворих на ЦД при застосуванні антиоксидантної терапії

\begin{tabular}{|c|c|c|c|c|c|}
\hline \multirow{2}{*}{ Досліджувальні показники } & \multirow{2}{*}{ Одиниці виміру } & \multicolumn{3}{|c|}{ Періоди дослідження } & \multirow{2}{*}{ Референтні значення } \\
\hline & & 1-ша доба & 7-ма доба & 14-та доба & \\
\hline Активність СОД & Од./мг білка & $0,16 \pm 0,007^{*}$ & $0,16 \pm 0,005^{*}$ & $0,18 \pm 0,007^{* * * *}$ & $0,25 \pm 0,02$ \\
\hline ТБК-активні продукти & мкмоль/мл & $1,61 \pm 0,06^{*}$ & $1,59 \pm 0,05^{*, * *}$ & $1,57 \pm 0,02^{*, * *}$ & $1,01 \pm 0,02$ \\
\hline Е220 (дієнові кон'югати) & y.o. & $4,70 \pm 0,14^{*}$ & $4,37 \pm 0,15^{*}$ & $3,91 \pm 0,1^{* * * *}$ & $0,80 \pm 0,10$ \\
\hline S-нітрозотіоли & нмоль/мл & $1,91 \pm 0,04^{*}$ & $1,87 \pm 0,06^{*}$ & $1,81 \pm 0,02^{*}$ & $0,857 \pm 0,142$ \\
\hline
\end{tabular}

*Вірогідно порівняно з референтними показниками; **вірогідно по відношенню до вихідних показників. 
Таблиця 2 Показники функціональної активності моноцитів периферичної крові в НСТ-тесті у хворих на ЦД при застосуванні антиоксидантної терапії

\begin{tabular}{|c|c|c|c|c|c|}
\hline \multirow{2}{*}{ Досліджувані показники } & \multirow{2}{*}{ Од. виміру } & \multicolumn{3}{|c|}{ Періоди дослідження } & \multirow{2}{*}{ Референтні значення } \\
\hline & & 1-ша доба & 7-ма доба & 14-та доба & \\
\hline Спонтанний НСТ-тест & $\%$ & $5,21 \pm 0,42^{*}$ & $6,42 \pm 0,57^{*}$ & $6,74 \pm 0,63^{*}$ & $11,10 \pm 0,74$ \\
\hline Індукований НСТ-тест & $\%$ & $2,35 \pm 0,17^{*}$ & $4,21 \pm 0,11^{*}$ & $6,03 \pm 0,15^{* * * *}$ & $12,25 \pm 0,17$ \\
\hline
\end{tabular}

*Biрогідно порівняно з референтними показниками; ** вірогідно порівняно з вихідними показниками.

Таким чином, у хворих на ЦД визначається висока активність реакцій, пов'язаних з вільнорадикальним утворенням, на тлі значного зниження антиоксидантної системи СОД, що зумовлює розвиток ангіопатій. Дієнові кон'югати, які $\epsilon$ первинними продуктами ПОЛ, чинять шкідливу дію на ліпопротеїди, білки, ферменти і нуклеїнові кислоти. При взаємодії діальдегіду з вільними групами мембранних сполук утворюються кінцеві продукти ПОЛ (основи Шиффа та ін.). Неконтрольоване накопичення цих продуктів призводить до ушкодження мембран таких клітин, як моноцити/макрофаги, клітини судинного епітелію, що $є$ причиною їх дисфункції, а у разі пошкодження моноцитів/макрофагів зниження неспецифічної антимікробної резистентності та імунологічної реактивності в цілому, розвитку аутоімунних реакцій.

\section{Висновки}

1. СДС - поширене та складне ускладнення ЦД, яке в структурі гнійно-запальних захворювань становить $14,1 \%$.

2. Лікування СДС $€$ комплексним і включає хірургічне лікування гнійно-некротичного вогнища з імобілізацією стопи, корекцію вуглеводного обміну, антибактеріальну, метаболічну, антикоагулянтну, ангіотропну, знеболювальну та протизапальну терапію.

3. Оксидативний стрес призводить до каскаду патоморфологічних змін в організмі, що диктує необхідність застосування антиоксидантної терапії в комплексному лікуванні СДС.

4. Застосування антиоксидантної терапії в комплексному лікуванні СДС зменшує вираженість оксидативного стресу і пов'язаного з ним пошкодження клітин судинного ендотелію, сприяє збереженню функціональної активності одних з основних еферентних клітин неспецифічного та адаптаційного імунітету на субкомпенсованому рівні.

\section{Список використаної літератури}

1. International Diabetes Federation (2019) Diabetes Atlas. 9th ed.

2. Kryzhevskyi Y., Bilyayeva 0., Rykov S. et al. (2021) Study of new pathogenetic mechanisms of diabetic retinopathy development in patients with diabetic foot syndrome. J. Educat. Health Sport, 11(04): 233-246. DOl dx.doi.org/10.12775/JEHS.2021.11.04.024.

3. Biliaieva 0.0., Rybianets Yu.V., Kryzhevskyi Ye.le. (2017) Porivnialna otsinka mistsevoho likuvannia hniino-nekrotychnykh uskladnen pry syndromi diabetychnoi stopy za dopomohoiu aplikatsiinykh sorbentiv. Suchasn. med. tekhnol., 4(35): 9-12 (In Ukr.).

4. Sibbald R., Ayello E. (2018) The Reduction of Diabetic Foot Amputations Starts with Preventing Foot Ulcers. Adv. Skin Wound Care, 31(9): 389. D0l: 10.1097/01.ASW.0000544473.65179

5. Prystupiuk 0.M. (2002) Oksydantnyi stres za naiavnosti tsukrovoho diabetu. UMJ, 3(29): 23-25.

6. Bolotova D.G., Lobanov S.L., Morozov E.Ju. (2007) Analiz lechenija gnojno-nekroticheskih form sindroma diabeticheskoj stopy. Bjul. VSNC SO RAMN, 4: 38-39.

7. Bregovskij V.B., Zajeev A.A., Zelevskaja A.G. (2004) Porazhenie nizhnih konechnostej pri saharnom diabete. Medicina, $354 \mathrm{~s}$.

8. Kozlov V.I. (2003) Gistofiziologiya sistemy mikrocirkulyacii. Regionarnoe krovoobrashchenie i mikrocirkulyaciya, 4: 79-85.

9. Pereira M.A., Sanomiya P., Leme J.G. (1987) Inhibition of leukocyte chemotasis by factor in alloxan-induced diabetic rat plasma. Diabete, 36(8): 1307-1314.

10. Kryzyna 0.V. (2018). Patomorfologichni osoblyvosti krovopostachannja m'jakyh tkanyn nyzhnih kincivok pry cukrovomu diabeti. Visn. probl. biol. med., 4(1): 20-24.

11. Lankin V.Z., Tikhaze A.K., Belenkov Yu.N. (2000) Free radical processes in diseases of the cardiovascular system. Cardiology, 40(7): 48-61 (In Rus.).

12. Shih E.V., Petunina N.A., Nedosugova L.V. et al. (2020) Spontannaja i inducirovannaja sekrecija provospalitel'nyh i protivovospalitel'nyh citokinov u pacientov s saharnym diabetom 2 tipa i sindromom diabeticheskoj stopy. Saharnyj diabet, 23(3): 210-222 (In Rus.).
13. Kulinskij V.I. (1999) Aktivnye formy kisloroda i oksidativnaya modifikaciya makromolekul: pol'za, vred i zashchita. Sorosovskij obrazovatel'nyj zhurnal, 1:2-7.

14. Anderson M.E. (1989) Enzymatic and chemical methods for the determination of glutathione. Glutathion, pt A.: 339-366.

15. Tsunada S., Iwakiri R., Noda T. et al. (2003) Chronic exposure to subtoxic levels of peroxidized lipids suppresses mucosal cell turnover in rat small intestine and reversal by glutathione. 48(1): 210-222. doi: 10.1023/a:1021775524062

16. Meister A., Anderson M.E. (1983) Glutathione. Ann. Rev. Biochem., 52:711-760. doi: 10.1146/ annurev.bi.52.070183.003431.

17. Kulinskij V.I., Kolesnichenko L.S. (2009) Sistema glutationa 1. Sintez, transport glutationtransferazy, glutationperoksidazy. Biomed. himiya, 55(3): 255-277 (In Rus.).

18. Deneke S.M., Fanburg B.Y. (1989) Regulation of cellular glutathione. Am. J. Physiol., 257(4 Pt. 1): 163-173. doi: 10.1152/ajplung.1989.257.4.L163.

19. Sies H., Graf P. (1985) Hepatic thiol and glutathione efflux under the influence of vasopressin, phenylephrine and adrenaline. Biochem. J., 226(2): 545-549. doi: 10.1042/bj2260545

20. Meggitt B. (1976) Surgical management of the diabetic foot. Br. J. Hosp. Med., 16:227-332.

21. Wagner F. (1979) A classification and treatment program for diabetic, neuropathic, and dysvascular foot problems. Instr. Course Lect., 28(1): 143-165.

22. Monteiro-Soares M., Boyko E., Jeffcoate W. et al. (2020) Diabetic foot ulcer classifications: A critical review. Diabetes Metab. Res. Rev., 36 Suppl. 1: e3272. doi: 10.1002/dmrr.3272

23. American Diabetes Association (2003) Peripheralarterial disease in people with diabetes. Diabetes Care, 26: 3333-3341. D01: 10.2337/diacare.26.12.3333.

24. Selyutina S.N., Selyutin A.Y., Pal A.I. (2000) Modification of the determination of the concentration of TBA-active products of blood serum. Klin. lab. Diagnostics, 2: 8-11.

25. KostjukV.A., Potapovich A. I., Kovaleva Zh.V. (1990) Prostoji churstvitel'nyj metod opredelenija aktivnosti superoksiddismutazy, osnovannyj na reakcii okislenija kvercetina. Voprosy medicinskoj himii, 36(2): $88-91$ (In Rus.).

26. Vanin A.F. (1998) Dinitrozil'nye kompleksy zheleza iS-nitrozotioly — dve vozmozhnye formy stabilizacii i transporta oksida azota v biosistemah. Biohimija, 63(7): 924-938 (In Rus.).

27. Jourd'heuil D., Hallén K., Feelisch M., Grisham M.B. (2000) Dynamic state of S-nitrosothiols in human plasma and whole blood. Free Radic. Biol. Med., 28(3): 409-417. doi: 10.1016/ s0891-5849(99)00257-9.

28. Koval'chuk L.V. i dr. (2010) Immunologija: praktikum. GJeONTAR-media, 176 s. (In Rus.).

29. Dedov I.I., Udovichenko O.V., Galstyan G.R. (2005) Diabeticheskaya stopa. Prakt. Medicina, 197 s. (In Rus.).

\section{Substantiation of the use of antioxidant therapy in the complex conservative treatment of diabetic foot syndrome}

\section{O.0. Bilyayeva' ', O.I. Osadchaya ${ }^{2}$, Ye.Ye. Kryzhevskyi', A.R. Bitinsh'}

'Shupyk national healthcare university of Ukraine, Kiev, Ukraine ${ }^{2}$ National university of physical education and sports of Ukraine, Kiev, Ukraine

Abstract. Aim: to study the state of the antioxidant system of patients with diabetic foot syndrome and to improve the results of their complex treatment. Object and methods of research. The study included 134 patients with diabetic foot syndrome. Patients were divided by sex and age: men -85 (63.4\%), women - 49 (36.6\%), the average age was (64.3 \pm 7.3 years). To study the antioxidant system, we determined for 1, 7, 14 days in the wound and serum the content of metabolites of reactive oxygen species of TBA-active products in blood plasma, the activity of the antioxidant system superoxide dismutase. Peripheral blood monocyte functional activity was assessed in the nitrosine tetrazolium reduction test in two modifications: spontaneous and lipopolysaccharide-induced. Results. When determining the 
activity of superoxide dismutase in peripheral blood in patients who received glutathione in complex treatment, we found a decrease in its activity relative to reference values 1.56 times $(p<0.001)$. Conclusions. Oxidative stress leads to a cascade of pathomorphological changes in the body, which dictates the need to use antioxidant therapy in the treatment of diabetic foot syndrome.

Key words: diabetic foot syndrome, diabetes mellitus, antioxidant system.

\section{Відомості про авторів:}

Біляєва Ольга Олександрівна — доктор медичних наук, професор кафедри загальної та невідкладної хірургії Національного університету охорони здоров'я України імені П.Л. Шупика, Київ, Україна. ORCID ID: 0000-0003-2862-0423

Осадча Оксана Іванівна — кандидат біологічних наук, доцент кафедри спортивної медицини Національного університету фізичного виховання і спорту України, Київ, Україна. ORCID ID: 0000-0001-5883-425X Крижевський Євгеній Євгенійович — аспірант кафедри загальної та невідкладної хірургії Національного університету охорони здоров'я України імені П.Л. Шупика, Київ, Україна. ORCID ID: 00000003-1403-1476

Бітіньш Андрій Русланович — лікар-інтерн кафедри загальної та невідкладної хірургії Національного університету охорони здоров'я України імені П.Л. Шупика, Київ, Україна. ORCID ID: 0000-00033867-5524

\section{Адреса для кореспонденції:}

Біляєва Ольга Олександрівна

03680, Київ, пр. Комарова, 3

E-mail: pr.bilyayeva@gmail.com

\section{Information about the authors:}

Bilyayeva Olga 0. - MD, Dr. Sc., Full Professor, Shupyk National Healthcare University of Ukraine, Department of General and Emergency Surgery, Kyiv, Ukraine. ORCID ID: 00000003-2862-0423

Osadchaya 0ksana I. - PhD in Biology, Associate Professor of the Department of Sports Medicine of the National University of Physical Education and Sports of Ukraine, Kyiv, Ukraine. ORCID ID: 0000-0001-5883-425X

Kryzhevskyi Yevhenii Ye. - postgraduate student of Shupyk National Healthcare University of Ukraine, Department of General and Emergency Surgery, Kyiv, Ukraine. ORCID ID: 0000-0003-1403-1476

Bitinsh Andrii R. — Intern, Shupyk National Healthcare University of Ukraine, Department of General and Emergency Surgery, Kyiv, Ukraine. ORCID ID: 0000-0003-3867-5524

\section{Address for correspondence:}

Olga Bilyayeva

03680, Kyiv, Komarov ave., 3

E-mail: pr.bilyayeva@gmail.com 